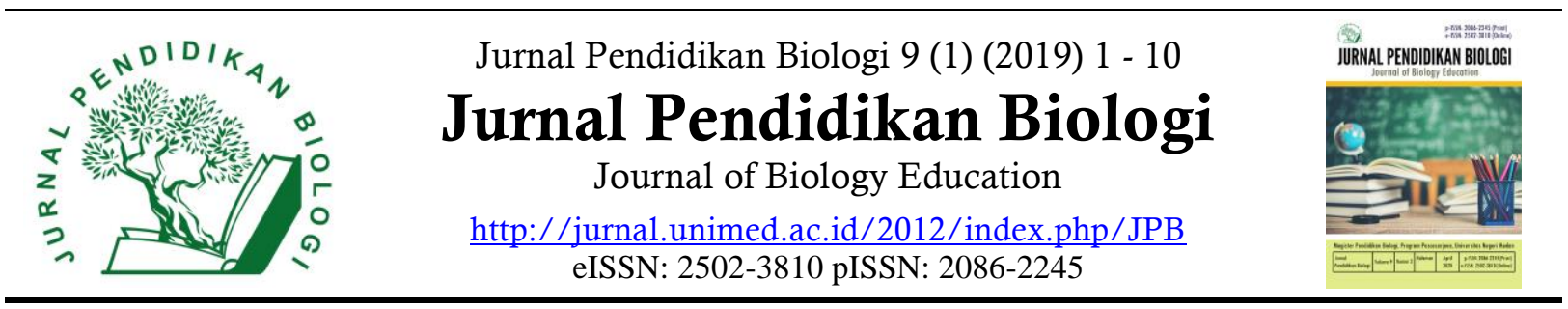

\title{
Profil Keterampilan Regulasi Metakognisi Ditinjau dari Strata Angkatan Mahasiswa Pendidikan Biologi
}

\author{
Roisyah Ashshaddiqah Suwandi, Amelia Happy Beauty, Avis Alfara, Fattahu Husna \\ Nurisma, Sulis Pujiyanti, Baskoro Adi Prayitno*
}

Jurusan Pendidikan Biologi, Fakultas Keguruan dan Ilmu Pendidikan, Universitas Sebelas Maret, Jl. Ir. Sutami No.36 A Kota Surakarta, Jawa Tengah

\section{INFO ARTIKEL}

\section{Histori Artikel}

Received 26 September 2019

Revised 28 Januari 2020

Accepted 4 April 2020

Published 30 September 2020

\section{Keywords:}

Metacognitive Awareness

Inventory,

Metacognition skill,

Metacognition regulation

\begin{abstract}
This research aims to determine the profile of metacognition regulation skills and determine the differences in metacognition regulation skills of Biology Education students at one of the Universities in Surakarta based on the strata of the class. This research method uses a survey method. The research population was Biology Education students at one of the Universities in Surakarta consisting of 4 classes totaling 240 students. The research sample was obtained by stratified random sampling technique as much as $30 \%$ of the population, namely 18 students per class. The research data was obtained through a questionnaire that referred to the Metacognitive Awareness Inventory (MAI) with indicators of Metacognitive Regulations, including Planning, Information Strategy, Monitoring, Coordination Errors, Understanding Strategies, and Evaluation. Analysis of research data was carried out in quantitative descriptive and ANAVA test. The results of the research showed that the profile of metacognition regulation skills in each class averaged $79.51 \%$ with a well-developed category. The profile of the 2015 metacognition regulation skills is $77.80 \%$ with a category that has developed well, the 2016 class is $82.48 \%$ with a category that has developed well, the 2017 class is $79.81 \%$ with a well-developed category, and 2018 is $79,97 \%$ with a well developed category. Skill in regulating metacognition of Biology Education students in Surakarta in 2018/2019 has developed well. The 2016 Biology Education students have the highest average metacognition skills with a score of $82.48 \%$. ANAVA test results showed no difference in metacognitive regulation for each class with a significance value of 0.054 .
\end{abstract}

Copyright (C) 2020 Universitas Negeri Medan. Artikel Open Access dibawah lisensi CC-BY-4.0 (https://creativecommons.org/licenses/by/4.0)

\section{How to Cite}

Suwandi, R. A., Beauty, A. M., Alfara, A., Nurisma, F. H., Pujiyanti, S., Prayitno, B. A. (2020). Profil Keterampilan Regulasi Metakognisi Ditinjau dari Strata Angkatan Mahasiswa Pendidikan Biologi. Jurnal Pendidikan Biologi, 9(1), 1-10. 


\section{PENDAHULUAN}

Keterampilan yang digunakan pada abad 21 harus relevan terhadap 4 pilar kehidupan antara lain : learning to know, learning to do, learning to be dan learning to live together. Prinsipprinsip tersebut perlu dikembangkan melalui kegiatan belajar, seperti kemampuan dalam pemecahan masalah, berpikir kritis, berpikir metakognisi, berkomunikasi, berkolaborasi, kreasi dan inovasi, literasi informasi, dan lainlain (Pertiwi, et al., 2018). Pendapat lain menyatakan bahwa terdapat 10 keterampilan yang harus dimiliki oleh siswa abad 21, antara lain: keterampilan berpikir kritis, memimpin, komunikasi, kolaborasi, adaptasi, produktifitas, akuntabilitas, inovasi, kewarganegaraan, jiwa entrepreneurship, kemampuan mengakses, mensintesis, menganalisis informasi (Barry, 2012).

Menurut Assessment and Teaching of 21st Century Skills (ATC21S), keterampilan abad terbagi menjadi 4 kategori, yaitu way of thinking, way of working, tools for working dan skills for living in the world (Griffin, et al., 2012). Pada poin Way of thinking mencakup inovasi, kreativitas, berpikir kritis, memecahkan masalah, dan membuat keputusan. Way of working mencakup keterampilan komunikasi, kolaborasi dan kerjasama tim. Tools for working mencakup kesadaran global dan lokal, pengembangan hidup, karir, dan rasa tanggung jawab pribadi serta sosial, sedangkan skills for living in the world mencakup ketrampilan mencari literasi informasi, teknologi informasi, komunikasi, kemampuan belajar dan bekerja melalui sosial digital.

Metakognisi merupakan istilah yang meliputi apa yang diketahui oleh seorang siswa tentang diri sendiri sebagai seorang pelajar yang belajar dan bagaimana cara dia mengatur dan menyesuaikan perilakunya (Suherman, 2003). Menurut Schoenfeld di dalam (Budi et al., 2017), metakognisi tersebut ada hubungannya dengan pola pikir seorang siswa menyangkut dirinya sendiri dan kemampuannya dalam menguasai strategi belajar secara tepat Menurut Concepción (2004), metakognitif terdiri dari pengetahuan metakognitif (metakognitive knowledge) dan pengalaman atau pengaturan metakognitif (metakognitif experience or regulation) pada suatu aktivitas kognitif seseorang dalam proses belajarnya. Peserta didik yang kemampuan metakognisi berkembang dan diasah secara sengaja dalam aktivitas pembelajarannya dapat menjadikan dirinya sebagai pembelajar yang mandiri.

Paidi (2009) dalam Wibowo, Widowati, \& Krisnawati (2012) melakukan penelitian mengenai kemampuan metakognisi mahasiswa di Pendidikan Biologi Universitas Negeri Yogyakarta dan hasilnya menunjukkan bahwa kemampuan metakognisi mahasiswa Pendidikan Biologi Universitas Negeri Yogyakarta tergolong berkembang baik dengan skor kemampuan metokognisi sebesar 70,95\%. Mazancieux et al. (2016) melakukan penelitian untuk mengetahui pola keterampilan berpikir kritis dan metakognitif mahasiswa di Program Studi Pendidikan Biologi Universitas PGRI Semarang yang menunjukan bahwa keterampilan metakognitif mahasiswa Program Studi Pendidikan Biologi Universitas PGRI Semarang tergolong cukup baik, yaitu memiliki skor sekitar $66.74 \%$. Baik mahasiswa Pendidikan Biologi UNY maupun Universitas PGRI Semarang, keduanya menunjukan hasil yang cukup baik, namun untuk level mahasiswa dengan perkembangan kemampuan berpikir tingkat tinggi serta tuntutan abad 21, seharusnya keterampilan metakognitif mahasiswa dapat lebih tinggi.

Kemampuan metakognisi diperlukan untuk memastikan seseorang memiliki cognitive control dan self regulatory yang membuat proses merancang strategi terbaik dalam memilih, mengingat, mengenali 
kembali, mengorganisasi informasi yang dihadapinya, serta dalam menyelesaikan masalah menjadi lebih baik lagi (Asmarani, 2016). Berfikir metakognitif memastikan bahwa individu mampu menyusun makna informasi (Hall, 2008). Mahasiswa yang mampu memanajemen metakognisi dengan baik, mampu menunjukkan performa belajar yang baik pula. Individu mampu memanajemen metakognisi sehingga dapat mempengaruhi komunikasi mereka. Kemampuan tersebut antara lain: (a) individu dapat memahami bahwa mereka mempunyai pikiran dengan kapasitas untuk berpikir luar biasa secara sadar yang dapat mereka kembangkan; (b) individu dapat lebih efisien dalam berpikir tentang pikiran mereka jika mereka memandang proses mental yang mereka miliki merupakan keterampilanketerampilan yang dapat mereka latih; dan (c) pada kehidupan sehari-hari, individu dapat mempraktikkan dengan tekun menggunakan keterampilan pikiran untuk mempengaruhi komunikasi mereka. Berdasarkan pernyataan tersebut, dapat disimpulkan bahwa melalui manajemen metakognisi maka mahasiswa mampu menyadari bahwa mereka mempunyai potensi untuk memproduksi pikiran-pikiran yang luar biasa, mampu melatih keterampilan berpikir sehingga lebih efisien, dan mampu memproduksi kegiatan belajar dengan performa maksimal dalam mempelajari materi mata kuliah (Nelson-Jones, 2015).

Berbagai penelitian di atas menunjukkan bahwa metakognisi memegang peran yang sangat penting dalam aktivitas pembelajaran mahasiswa dalam mengikuti perkuliahan. Melalui kegiatan pengaturan diri, refleksi terhadap kelemahan dan kekuatan atas apa yang telah dilakukan serta strategi pembelajaran yang telah diupayakan, maka mahasiswa akan mampu meningkatkan kualitas proses maupun hasil belajar. Oleh karena itu, tujuan penelitian ini adalah mengetahui keterampilan regulasi metakognisi yang dimiliki oleh mahasiswa Pendidikan Biologi di salah satu Universitas di Surakarta Tahun Pelajaran 2018/2019 yang terdiri dari 4 strata angkatan.

\section{METODE}

Jenis penelitian ini adalah penelitian deskriptif kuantitatif dengan metode survei. Populasi penelitian adalah mahasiswa Pendidikan Biologi di salah satu Universitas di Surakarta yang terdiri dari 4 angkatan dengan jumlah mahasiswa tiap angkatan 2015 sebanyak 58 mahasiswa, 2016 sebanyak 60 mahasiswa, 2017 sebanyak 57 mahasiswa, dan 2018 sebanyak 65 mahasiswa sehingga total mahasiswa 4 angkatan adalah 240 mahasiswa. Sampel penelitian diperoleh dengan teknik stratified random sampling dengan menggunakan strata angkatan mahasiswa. Sampel penelitian diambil sebanyak $30 \%$ dari populasi yaitu 72 mahasiswa dengan tiap angkatan diambil secara acak sejumlah 18 mahasiswa.

Keterampilan regulasi metakognisi diukur menggunakan (Metakognitive Awareness Inventory/ MAI) yang diadaptasi dari Schraw dan Dennison (1994) dengan indikator regulasi metakognisi, meliputi planning, strategi informasi, monitoring, strategi koordinasi kesalahan pemahaman, dan evaluasi. Soal MAI terdiri atas 35 butir pernyataan dengan kriteria skor 0-20 menunjukan keterampilan regulasi metakognisi belum berkembang, skor 21-40 menunjukan keterampilan regulasi metakognisi masih sangat beresiko, skor 41-60 menunjukan keterampilan regulasi metakognisi mulai berkembang, skor 61-80 menunjukan keterampilan regulasi metakognisi berkembang baik dan skor 81-100 menunjukan keterampilan regulasi metakognisi berkembang sangat baik. Prosedur pengambilan data dilakukan dengan 
pembagian soal pada masing-masing mahasiswa dengan waktu pengerjaan 15 menit.

Analisis data penelitian dilakukan secara deskriptif kuantitatif dan ANAVA. Analisis deskriptif kuantitatif digunakan untuk mengetahui profil keterampilan regulasi metakognisi mahasiswa. Analisis ANAVA digunakan untuk mengetahui perbedaan keterampilan regulasi metakognisi pada 4 strata angkatan mahasiswa. Perhitungan statistik dilakukan menggunakan aplikasi SPSS versi 16.0 programs for windows dengan menggunakan taraf signifikansi $5 \%$.

\section{HASIL DAN PEMBAHASAN}

\section{Profil Keterampilan Regulasi Metakognisi}

Berdasarkan penelitian yang telah dilakukan menggunakan angket regulasi metakognisi pada mahasiswa pendidikan biologi angkatan 2015, 2016, 2017, dan 2018, didapatkan hasil disajikan pada Tabel 1.

Total skor kemampuan regulasi metakognisi yang diperoleh mahasiswa Pendidikan Biologi di salah satu Universitas di Surakarta untuk semua angkatan termasuk dalam kategori berkembang baik. Pada angkatan 2015 dengan jumlah mahasiswa 58 mahasiswa, diambil sampel sebanyak 18 mahasiswa yang mewakili angkatan 2015. Rata-rata skor kemampuan regulasi metakognisi mahasiswa angkatan 2015 adalah 78,35\%. Angkatan 2015 memiliki skor kemampuan regulasi metakognisi cukup rendah dibanding dengan angkatan 2016, 2017 dan 2018. Hal ini dapat menyebabkan mahasiswa kurang menyadari akan pentingnya berpikir dan pentingnya kesadaran untuk mengatur proses berpikirnya. Metakognisi merupakan kemampuan menyelesaikan masalah (Ayu et al., 2019) dan dari data menunjukkan bahwa mahasiswa
Pendidikan Biologi angkatan 2015 memilki skor kemampuan regulasi metakognisi yang paling rendah dibandingkan angkatan 2016, 2017 dan 2018 sehingga dapat dilihat bahwa mahasiswa angkatan Pendidikan Biologi 2015 kurang mampu menyelesaikan masalah dibanding mahasiswa Pendidikan Biologi angkatan 2016, 2017 dan 2018.

Secara keseluruhan, angkatan 2016 memiliki kemampuan regulasi metakognisi yang sangat berkembang baik. Angkatan 2016 dengan jumlah sebanyak 60 mahasiswa, diambil sampel mahasiswa sebanyak 18 orang yang mewakili angkatan 2016. Rata-rata skor kemampuan regulasi metakognisi mahasiswa angkatan 2016 adalah 82,41\%. Angkatan 2016 yang memiliki skor kemampuan regulasi metakognisi tertinggi dibanding dengan angkatan 2015, 2017 dan 2018. Hal ini dapat menunjukkan bahwa mahasiswa Pendidikan Biologi angkatan 2016 menyadari akan pentingnya berpikir dan pentingnya kesadaran untuk mengatur proses berpikirnya. Foong (2002) berpendapat bahwa kemampuan regulasi metakognisi merupakan kemampuan menyelesaikan masalah sehingga mahasiswa yang memiliki kemampuan metakognisi dan proses berpikir yang baik cenderung memiliki kemampuan menyelesaikan masalah dengan baik. Data yang diperoleh dimenunjukkan bahwa mahasiswa Pendidikan Biologi angkatan 2016 memilki skor kemampuan regulasi metakognisi yang tertinggi dibandingkan angkatan 2015, 2017 dan 2018, sehingga dapat dilihat bahwa mahasiswa Pendidikan Biologi angkatan 2016 dirasa sudah mampu menyelesaikan masalah yang dihadapi dibanding mahasiswa Pendidikan Biologi angkatan 2015, 2017 dan 2018 dengan adanya proses identifikasi tugas, memantau pekerjaan, mengevaluasi kemajuan dan memprediksi hasil dari masalah yang sedang dihadapi. 
Tabel 1. Profil keterampilan regulasi metakognisi mahasiswa Pendidikan Biologi di salah satu Universitas di Surakarta

\begin{tabular}{ccccc}
\hline No & $\begin{array}{c}\text { Mahasiswa } \\
\text { Angkatan }\end{array}$ & $\begin{array}{c}\text { Keterampilan regulasi } \\
\text { metakognisi (\%) }\end{array}$ & Kategori & $\begin{array}{c}\text { Keterampilan regulasi } \\
\text { metakognisi } \\
\text { keseluruhan }\end{array}$ \\
\hline 1 & 2015 & $78,35 \%$ & berkembang baik & \\
2 & 2016 & $82,41 \%$ & $\begin{array}{c}\text { berkembang sangat baik } \\
\text { berkembang baik }\end{array}$ & $\begin{array}{c}79,06 \% \\
\text { ( berkembang baik) }\end{array}$ \\
3 & 2017 & $78,57 \%$ & berkembang baik & \\
\hline
\end{tabular}

Angkatan 2017 juga memiliki kemampuan metakognisi dengan kategori berkembang baik. Dari 57 orang mahasiswa, diambil sampel mahasiswa sebanyak 18 orang yang mewakili angkatan 2017. Rata-rata skor kemampuan regulasi metakognisi mahasiswa angkatan 2017 adalah 78,57\%. Angkatan 2017 yang memiliki skor kemampuan regulasi metakognisi yang cukup tinggi dibandingkan dengan mahasiswa Pendidikan Biologi angkatan 2015 dan 2018 namun kurang tinggi dibandingkan dengan mahasiswa Pendidikan Biologi angkatan 2016, sehingga dapat dilihat bahwa mahasiswa Pendidikan Biologi angkatan 2017 dirasa sudah cukup mampu untuk menyelesaikan masalah yang dihadapi dibandingkan dengan mahasiswa Pendidikan Biologi angkatan 2015 dan 2018 dengan adanya proses identifikasi tugas, memantau pekerjaan, mengevaluasi kemajuan dan memprediksi hasil dari suatu penyelesaian masalah. Menurut Pai'pinan (2015) kemampuan regulasi metakognisi akan berkembang jika sering digunakan dalam lingkungan metakognitif, sehingga mahasiswa yang terbiasa menyelesaikan masalah cenderung memiliki kemampuan regulasi metakognisi yang baik.

Angkatan 2018 merupakan angkatan yang memiliki komponen metakognisi yang termasuk dalam kategori berkembang kurang baik, yaitu 76,89\%. Dari 65 orang mahasiswa, diambil sampel mahasiswa sebanyak 18 orang yang mewakili angkatan 2018. Hal ini menunjukkan bahwa mahasiswa Pendidikan Biologi angkatan 2018 memiliki kemampuan regulasi kognisi yang lebih tinggi dibandingkan dengan mahasiswa Pendidikan Biologi angkatan 2015, namun kurang tinggi dibandingkan dengan mahasiswa Pendidikan Biologi angkatan 2016 dan 2017. Hal ini menunjukkan bahwa perlu adanya peningkatkan akan pentingnya menyadari cara berpikir dan pentingnya kesadaran untuk mengatur proses berpikir, karena kemampuan regulasi metakognisikognisi merupakan kemampuan menyelesaikan masalah (Foong, 2002).

Rata-rata skor kemampuan metakognisi mahasiswa program studi S1 Pendidikan Biologi FKIP di salah satu Universitas di Surakarta yaitu sebesar 79,06\% dan termasuk kedalam kategori berkembang baik. Kemampuan regulasi metakognisi disetiap jenjang usia berbeda-beda bergantung pada pertambahan usia mahasiswa dan perkembangan sesuai dengan perambahan usia. Semakin usia bertambah, maka semakin tinggi pula kemampuan regulasi metakognisi disetiap jenjang usia (Schunk, et al., 2012). Kemampuan regulasi metakognisi mahasiswa pada program studi S1 Pendidikan Biologi FKIP disalah satu Universitas di Surakarta seharusnya mengalami penigkatan mulai dari mahasiswa angkatan terakhir sampai mahasiswa angkatan awal, walaupun dalam setiap angkatan terdapat perbedaan kemampuan regulasi metakognisi antara 
perseorangan. Dilihat dari pernyataan tersebut, seharusnya mahasiswa Pendidikan Biologi angkatan lebih awal dengan usia yang lebih tua dan perkembangan diri yang lebih baik akan memiliki kemampuan regulasi metakognisi yang lebih tinggi dibandingkan dengan mahasiswa Pendidikan Biologi angkatan terakhir. Namun dari data dimenunjukkan bahwa mahasiswa dengan kemampuan regulasi mrtakognisi yang lebih tinggi adalah dari angkatan 2016 dengan skor rata-rata adalah 82,41\%, lalu angkatan 2017 dengan skor rata-rata adalah 78,57\%, lalu angkatan 2018 dengan skor rata-rata adalah 76,89\%, baru angkatan 2015 dengan skor ratarata adalah $78,35 \%$.

Faktor yang mempengaruhi kemampuan regulasi metakognisi mahasiswa meliputi proses pembelajaran, model pembelajaran yang diajarkan, strategi-srategi belajar, ketersediaan fasilitas belajar dan kesempatan dalam mengutarakan ide atau pikiran (Arifin \& Saenab, 2014). Angkatan 2015 merupakan angkatan yang sebagian besar waktunya digunakan untuk mengerjakan skripsi, sehingga sudah tidak mengikuti proses pembelajaran di dalam kelas. Hal ini mempengaruhi keterampilan regulasi metakognisi mahasiswa angkatan 2015 yang lebih rendah daripada angkatan lainnya karena strategi belajar yang berubah dari aktif mengerjakan tugas kuliah dan mengatur strategi belajar yang sesuai menjadi terfokus hanya pada skripsi. Sementara angkatan 2016 memiliki keterampilan regulasi metakognisi yang lebih tinggi dibandingkan dengan angkatan lainnya yang mengindikasikan bahwa angkatan 2016 dalam mengikuti proses perkuliahan telah memiliki pengaturan diri, refleksi terhadap kelemahan dan kekuatan serta mengatur strategi belajar yang sesuai untuk meningkatkan kualitas proses maupun hasil belajar. Hasil tersebut sejalan dengan hasil penelitian Arief et al. (2011) yang menunjukan kemampuan merancang strategi belajar dan kemampuan menilai strategi belajar mahasiswa semester 2 dan 4 berkembang sangat baik, sedangkan mahasiswa semester 6,8 , dan 10 berada pada tahap sudah berkembang.

Adanya perbedaan kategori kemampuan regulasi metakognisi pada masing-masing angkatan mengindikasikan bahwa pembelajaran Biologi yang berlangsung dalam perkuliahan sudah menunjukkan proses pembelajaran yang mengarah pada perkembangan terhadap peningkatan kemampuan berpikir mahasiswa, khususnya kemampuan regulasi kognisi mahasiswa. Pada umumnya, mahasiswa mampu memanfaatkan kemampuan regulasi kognisi mereka sehingga terjadi interaksi antara pengetahuan metakognisi, pengalaman metakognisi, tujuan dan strategi (Pai'pinan, 2015) yang artinya kemampuan regulasi kognisi akan berkembang jika digunakan dalam lingkungan metakognitif. Keterlibatan kemampuan perseorangan, bentuk penugasan, dan strategi pembelajaran dalam kelas akan dapat membentuk kemampuan regulasi kognisi dengan matang. Hal ini menunjukkan pentingnya pengembangan kemampuan berpikir mahasiswa yang akan mengarah pada peningkatan hasil belajar mahasiswa, sehingga dapat meningkatkan mutu dan kualitas mahasiswa Pendidikan Biologi di salah satu Universitas di Surakarta sebagai calon guru Biologi.

Beberapa strategi dapat dilakukan oleh pendidik dalam meningkatkan kemampuan metakognisi, seperti yang diungkapkan oleh Abdillah (2011) sebagai berikut: Pertama, membantu peserta didik dalam mengembangkan strategi dan mendorong peserta didik dalam memonitor proses berpikirnya, membimbing peserta didik dalam 
mengembangkan strategi belajar efektif, membantu peserta didik dalam memprediksi materi pembelajaran yang akan diberikan berikutnya, membimbing kebiasaan belajar dengan cara bertanya, dan menunjukkan kepada peserta didik bagaimana cara mentransfer pengetahuan, sikap, nilai, dan keterampilan dari masing-masing situasi. Kedua, mengembangkan kebiasaan peserta didik melalui pengembangan kebiasaan mengolah diri sendiri dan berpikir positif. Metakognisi tidak dapat diwariskan, namun dapat diajarkan secara berulang melalui pendekatan pembelajaran langsung. Melalui berbagai aktivitas, seperti menulis jurnal, menyampaikan pemikiran, bertanya pada diri sendiri, dan diharapkan kemampuan metakognisi peserta didik akan tumbuh dan dapat diterapkan dalam menyelesaikan berbagai tugas belajar di lingkungan pendidikan dilanjutkannya ketika bekerja dan beraktivitas di tengah masyarakat sepanjang hayat (Djuanda, 2008).

Tabel 2. Keterampilan regulasi metakognisi untuk setiap komponen regulasi metakognisi mahasiswa Pendidikan Biologi di salah satu Universitas di Surakarta

\begin{tabular}{lcccc}
\hline \multicolumn{1}{c}{ Komponen Metakognisi } & \multicolumn{3}{c}{ Angkatan } \\
\cline { 2 - 5 } & $\mathbf{2 0 1 5}$ & $\mathbf{2 0 1 6}$ & $\mathbf{2 0 1 7}$ & $\mathbf{2 0 1 8}$ \\
\hline Planning & $80,48 \%$ & $81,11 \%$ & $82,70 \%$ & $80 \%$ \\
Strategi Informasi & $78 \%$ & $82 \%$ & $78,67 \%$ & $71,67 \%$ \\
Monitoring & $76,03 \%$ & $78,57 \%$ & $76,83 \%$ & $79,21 \%$ \\
Strategi Koordinasi Kesalahan & $78,89 \%$ & $85,33 \%$ & $79,78 \%$ & $80,67 \%$ \\
Pemahaman & & & & $76,11 \%$ \\
Evaluasi & $78,70 \%$ & $86,67 \%$ & $74,63 \%$ & \\
\hline
\end{tabular}

Komponen pada keterampilan regulasi metakognisi antara lain adalah Planning, strategi informasi, monitoring, strategi koordinasi kesalahan pemahaman, dan evaluasi. Kemampuan planning merupakan salah satu komponen regulasi metakognisi. Kemampuan planning adalah kemampuan dalam merencanakan aktivitas belajar (Pujiank, 2016). Rata-rata kemampuan planning yang dimiliki mahasiswa adalah 81,07 $\%$ dengan perolehan skor angkatan 2015 sebesar 80,48\%, angkatan 2016 sebesar 81,11\%, angkatan 2017 sebesar 82,70\% dan angkatan 2018 sebesar 80\%. Data tersebut menunjukkan bahwa semua mahasiswa sudah mampu merencanakan aktivitas dalam belajar. Kemampuan planning sangat dibutuhkan agar pembelajaran dapat berlangsung secara terarah dan tujuan pembelajaran dapat terpenuhi. Kemampuan planning memberikan keahlian kepada mahasiswa dalam memprediksi dan menata keinginan dalam proses pembalajaran yang akan berdampak dalam jangka panjang (Paidi, 2011).

Komponen strategi informasi merupakan kemampuan dalam mengolah informasi dalam memori dana menggunakan strategi efektif dalam membuat informasi secara bermakna. Rata-rata kemampuan Komponen strategi informasi yang dimiliki mahasiswa adalah $77,58 \%$ dengan perolehan skor angkatan 2015 sebesar 78\%, angkatan 2016 sebesar $82 \%$, angkatan 2017 sebesar $78,67 \%$ dan angkatan 2018 sebesar 71,67\%. Dalam kurva, nilai strategi informasi ini memiliki kurva lebih rendah dibandingkan dengan komponen planning.terdapat dua kategori kemampuan metakognisi yang dapat sekaligus dikuasai oleh mahasiswa, yaitu kemampuan metamemory dan metacomprehension. Pada aktivitas metakognisi membuat digaram atau gambar secara bermasaan mampu membuat informasi yang didapat menjadi bermakna sehingga dapat disimpan dalam long term 
memory dan sekaligus meningkatkan pemahaman mahasiswa, sehingga membaantu dalam proses menghafal dalam proses pembelajaran biologi.

Komponen monitoring merupakan komponen yang meliputi penilaian terhadap pembelajaran atau strategi yang digunakan. Pemahaman ini tidak hanya sekedar tahu, tetapi juga menghendaki agar subjek belajar dapat memanfaatkan bahan- bahan yang telah dipahami melalui perhatian, tanggapan, sikap, dan perubahan tingkah laku dalam pembelajran. Komponen ini memiliki nilai masing- masing yaitu angkatan 2015 sebesar $76,03 \%$, angkatan 2016 sebesar 78,57\%, angkatan 2017 sebesar 76,83\% dan angkatan 2018 sebesar 79,21\%. Kurva pada komponen ini hampir sama dengan komponen strategi informasi. Melalui penilaian atau refleksi terhadap strategi pembelajaran tersebut, mahasiswa akan mampu mengetahui dan memahami strategi yang efektif digunakan dalam proses pembelajaran dan mampu menganalisis keberhasilan belajar yang telah dilakukan dengan menggunakan strategi tersebut.

Kemampuan strategi koordinasi kesalahan pemahaman adalah komponen yang meliputi kemampuan untuk memperbaiki pemahaman dan kinerja yang salah. Komponen ini memiliki masing-masing nilai yaitu angkatan 2015 sebesar 78,89\%, angkatan 2016 sebesar 85,33\%, angkatan 2017 sebesar 79,78\%, dan angkatan 2018 sebesar $80,67 \%$. Komponen ini memiliki kurva yang lebih tinggi dibandingkan dengan komponen monitoring dan bentuk kurva naik. Kemampuan ini meliputi meminta bantuan seseorang ketika tidak memahami materi, mengubah strategi yang digunakan ketika gagal dalam penggunaan sebelumnya, mengevaluasi sendiri konsep yang membingungkan, berhenti dan mengulang pada informasi yang belum jelas dipahami dan membaca ulang ketika merasa bingung.

Komponen terakhir adalah evalusasi. Komponen ini merupakan kemampuan seseorang dalam menganalisis kinerja atau efektifitas strategi yang digunakan pada kegiatan pembelajaran (Mukhidin, 2019). Nilai dari komponen evaluasi masing-masing angkatan yaitu, angkatan 2015 sebesar $78,70 \%$, angkatan 2016 sebesar 86,67\%, angkatan 2017 sebesar 74,63\%, dan angkatan 2018 sebesar 76,11\%. Pada kurva, komponen ini memiliki nilai yang lebih rendah jika dibandingkan dengan komponen strategi koordinasi kesalahan pemahaman namun lebih tinggi jika dibandingkan dengan komponen monitoring. Dalam kemampuan ini salah satunya adalah membuat catatan atau rangkuman setelah pembelajaran, yang merupakan strategi pendukung dalam proses menghafal (rehearsal) yang merupakan salah satu pendukung tahap pemrosesan informasi.

Tabel 3. Uji Perbedaan Keterampilan Regulasi Metakognisi Mahasiswa Pendidikan Biologi di salah satu Universitas di Surakarta

\begin{tabular}{lrrrrr}
\hline \multicolumn{1}{c}{ Keterampilan } & \multicolumn{2}{c}{ ANAVA } & \multicolumn{2}{c}{ Mean } & \multirow{2}{*}{ Sum of } \\
Regulasi Metakognisi & Squares & \multicolumn{1}{c}{ Df } & $\begin{array}{c}\text { Mean } \\
\text { Square }\end{array}$ & \multicolumn{1}{c}{ Sig. } \\
\hline Between Groups & 85.750 & 3 & 28.583 & 3.158 & 0,054 \\
Within Groups & 144.800 & 16 & 9.050 & & \\
Total & 230.550 & 19 & & & \\
\hline
\end{tabular}

Keterangan

- Apabila nilai signifikansi $>0,05$, maka tidak terdapat perbedaan antar strata angkatan

- Apabila nilai signifikansi < 0,05, maka terdapat perbedaan yang signifikan antar strata angkatan (Wagner, 2010). 
Berdasarkan hasil uji anava didapatkan nilai signifikansi sebesar 0,054 ( $p>0,05)$, maka dapat disimpulkan bahwa tidak terdapat perbedaan yang signifikan antar strata angkatan mahasiswa Pendidikan Biologi di salah satu Universitas di Surakarta sehingga tidak perlu dilakukan uji lanjut. Hal tersebut sesuai dengan penelitian Arifin \& Saenab (2014) yang menunjukan keterampilan regulasi metakognisi setiap strata angkatan tidak terdapat perbedaan yang signifikan karena dipengaruhi oleh beberapa faktor, meliputi kesadaran berpikir (perencanaan, strategi mengolah informasi, pemantauan diri, koordinasi kesalahan pemahaman, dan evaluasi), proses pembelajaran, model pembelajaran yang telah diajarkan mencakup pembelajaran kontruktivisme. Selain itu, terdapat pula faktor pengetahuan kognisi dimana pada umumnya, mahasiswa mampu memanfaatkan pengetahuan kognisi mereka sehingga terjadi interaksi antara pengetahuan metakognisi, pengalaman metakognisi, tujuan dan strategi (Pai'pinan, 2015). Faktor-faktor yang disebutkan telah dimiliki oleh setiap strata angkatan sehingga dapat dikatakan tidak ada perbedaan keterampilan regulasi metakognitif.

Sedangkan penelitian oleh Arief et al. (2011) dengan subyek penelitian adalah mahasiswa semester $2,4,6,8$ dan 10 menunjukan hasil yang sedikit berbeda, yaitu tingkat kemampuan metakognisi setiap strata angkatan akan semakin rendah sesuai dengan lama masa studi mahasiswa. Hal tersebut meliputi (1) kemampuan merancang startegi belajar, (2) kemampuan memilih dan menggunakan strategi, (3) kemampuan memantau dan menilai strategi belajar, (4) kemampuan memadukan strategi belajar, yang semuanya berada pada tahap sudah berkembang dan berkembang sangat baik.

\section{KESIMPULAN}

Berdasarkan hasil penelitian dan pembahasan disimpulkan bahwa (1) skor keterampilan regulasi metakognisi mahasiswa program S1 Pendidikan Biologi di salah satu universitas di Surakarta termasuk dalam kategori berkembang baik dengan rata-rata $79,06 \%$. Rata-rata skor tertinggi keterampilan regulasi metakognisi dimiliki oleh mahasiswa Pendidikan Biologi angkatan 2016 sebesar $82,48 \%$, diikuti oleh mahasiswa angkatan 2018 sebesar 79,97\%, kemudian angkatan 2017 sebesar 79,81\%, dan terakhir angkatan 2015 sebesar 77,80\%. (2) skor kemampuan regulasi metakognisi mahasiswa progran studi S1 Pendidikan Biologi di salah satu universiatas di Surakarta untuk setiap komponen dikategorikan berkembang baik $(71,67 \%-86,67 \%)$. (3) hasil uji ANAVA menunjukkan tidak terdapat perbedaan yang signifikan antar strata angkatan dengan nilai signifikansi sebesar 0,054. Hasil penelitian ini akan memberikan kontribusi riset pada sains terkait dengan keterampilan regulasi metakognisi yang harus dimiliki seseorang sebagai bekal abad 21. Keterampilan regulasi metakognisi berkaitan dengan pengalaman diri dalam memaknai proses berpikir dan untuk apa berpikir itu. Keterampilan regulasi metakognisi sebagai riset pengembangan di masa depan dalam semua bidang ilmu sehingga harus dilakukan pemberdayaan.

\section{DAFTAR PUSTAKA}

Abdillah, A. (2011). Hubungan Kemampuan Metakognitif dan Lingkungan Belajar Rumah Sakit dengan Kemampuan Pemecahan Masalah Asuhan Keperawatan pada Mahasiswa (Akademi Keperawatan Lumajang). Tesis di Bidang Pendidikan Profesi Kesehatan Program Pascasarjana UNS Surakarta.

Arief, R. H., Firdaus, \& Ar, N. R. (2011). Profil Kemampuan Metakognisi Mahasiswa Program 
Studi Pendidikan Biologi FKIP Universitas Riau Berdasarkan Tingkat Masa Studi. Biogenesis (Jurnal Pendidikan Sains dan Biologi), 8(1), 17-24

Arifin, Arifah Novia., Saenab, Sitti. (2014). Perbandingan Kesadaran Metakognitif Siswa Yang Diajar Menggunakan Model ProblemBased Instruction (Pbi) Dengan Kooperatif Tipe Think Pair Share (Tps). Jurnal Bionature, 15 (2), 81-89.

Asmarani, D., \& Sholihah, U. (2016). Karakteristik Metakognisi Mahasiswa Dalam Menyelesaikan Masalah Matematika Berdasarkan LangkahLangkah Polya Dan De Corte. Al-Khwarizmi: Jurnal Pendidikan Matematika dan Ilmu Pengetahuan Alam, 4. https://doi.org/10.24256/akh.v4i1.451

Ayu, N., Aritonng, R. (2019). Metode Kooperatif Jigsaw Sebagai Upaya Meningkatkan Kemampuan Metakognitif dan Prestasi Belajar Siswa. Juenal Keperawatan Vol.9 No.1p 1084ISSN : 2086-9703 e ISSN : 2621-7694

Barry, M. (2012). What skills will you need to succeed in the future? Phoenix Forward (online). Arizona: University of Phoenix

Budi M, Ipah., Ghofar, Azizul. (2017). Analisis Keterampilan Berpikir Kritis Dan Metakognitif Mahasiswa Program Studi Pendidikan Biologi. Bioma, 6 (1)

Concepción, D. W. (2004). Reading philosophy with background knowledge and metacognition. Teaching Philosophy, 27(4), 351368.

Djuanda, M. 2008. Urgensi Metakognitif Dalam Meningkatkan Mutu Pembelajaran di Madrasah, (Online), (http://bdkjakarta.kemenag.go.idindex.php?a= artikel \&id=884).

Foong, Pui Yee (2002). Using Short Open-Ended Mathematics Questions to Promote Thinking and Understanding. The Mathematics Education into the $21^{\text {st }}$ Century Project. Palermo, Italy

Griffin, P., McGaw, B. and Care, E. (eds). (2012). Assessment and Teaching of 21st Century Skills. Dordrecht: Springer.

Hall, C. W., \& Webster, R. E. (2008). Metacognitive and Affective Factors of College Students with and without Learning Disabilities. Journal of Postsecondary Education and Disability, 21(1), 32-41.
Mazancieux, A., Souchay, C., Casez, O., \& Moulin, C. (2018). Metacognition and selfawareness in Multiple Sclerosis. Cortex,1(1), 111. https://doi.org/10.1016/j.cortex .2018 .11 .012

Mukhidin, Esi Febrina. (2019). Metakognitif Sebagai Keterampilan Berfikir Tingkat Tinggi pada Pembelajaran Abad 21. Jurnal Ilmu Pendidikan dan Pengajaran, 6(1)

Nelson-Jones, R. (2015). Basic counselling skills: A Helper's Manual $4^{\text {th }}$ Edition. Sydney: SAGE Publications Ltd.

Paidi. (2009). Pengembangan Perangkat Pembelajaran dan Pengaruhnya terhadap Kemampuan Metakognitif, Pemecahan Masalah, dan Penguasaan Konsep Biologi. Jurnal Pendidikan Biologi UM, 1(1):20-29

Paidi. (2011). Pengembangan Perangkat Pembelajaran Biologi Berbasis Masalah. Jurnal Kependidikan, 41(2), 185-201

Pai'pinan, Maitus. (2015). Profil Metakognisi Mahasiswa Calon Guru Matematika dalam Menyelesaikan Masalah Terbuka Geometri Ditinjau dari Perbedaan Gender. Jurnal Ilmiah Matematika dan Pembelajarannya, 1(1), 66-79

Pertiwi, Faninda \& Ahmadi. (2018). Analisis Tingkat Kemampuan Metakognitif Mahasiswa Melalui MAI (Metacognitive Awareness Inventory) pada Eksperimen Berbasis Problem Solving.Kodifikasia, 12(35)

Pujiank, S., Jamaluddin, J., \& Hadiprayitno, G. (2016). Kemampuan Metakognisi Mahasiswa Program Studi Pendidikan Biologi FKIP Universitas Mataram. Jurnal Pendidikan, Teori, Dan Pengembangan, 1(10)

Schunk, D.H., Pintrich, P.R., \&Meece, J.L. (2010). Motivation in Education: Theory, Research, and Applications Third Edition. New Jersey: Pearson Education.

Suherman, E. (2003). Strategi pembelajaran matematika kontemporer. Bandung: Jica.

Wagner, T. (2010). Overcoming The Global Achievement Gap (online). Cambridge: Harvard University.

Wibowo, Y., Widowati, A., \& Krisnawati, T. (2012). Pengaruh Pembelajaran Diagram Roundhouse Terhadap Kemampuan Kognitif dan Metakognitif Siswa SMAN 1 Ngaglik Sleman Yogyakarta. Jurnal Bioedukasi, 5(2), 3949. 